\title{
D. João VI e a Administração Pública Brasileira
}

\section{Tomás de Vilanova Monteiro Lopes}

\section{C}

OM a transmigração da família real para o Brasil, operou-se grande mudança na administração pública brasileira. Como sede da monarquia portuguêsa que aqui se refugiava para não cair cativa dos exércitos franceses, precisava o Brasil dispor de melhor aparelhamento administrativo para os negócios internos que se tornavam, então, mais complexos e para as relações internacionais que daqui deveriam ser mantidas e que constituiam, para a antiga colônia, um campo de atividades inteiramente novo.

Essa grande transformação se processou, por assim dizer, de improviso, sem um plano amadurecido, através de atos com os quais se iam atendendo as mais prementes necessidades do govêrno e da administração $e$ as mais instantes exigências da vida da côrte. Disso dá bem uma idéia a variedade dos assuntos versados na legislação dos primeiros mesés da permanência de D, Joño VI no Brasil. O exame dos documentos da época demonstra que, antes mesmo de se constituir o govêrno, o que só se verificou em março de 1808, fundava-se a escola médico-cirúrgica da Bahia, instituia-se uma aula pública de economia politica e criava-se uma companhia de seguros.

Dir-se-á que tal ausência de plano encontra sua justificação no fato de ter sido a mudança da côrte feita precipitadamente, ante o perigo iminente da invasão de Portugal pelos exércitos de Bonaparte. Não teremos, entretanto, maior relutância em rejeitar essa explicação, se considerarmos que a transferência da monarquia portuguêsa para o Brasil vinha sendo prevista de longa data como solução para as dificuldades que Portugal enfrentava na Europa, em virtude da expansão do poderio das nações que com êle disputavam a posse das riquezas e o domínio do comércio internacional.

Sabe se mesmo que a primeira sugéstão no sentido da mudança da côrte portuguêsa para o Brasil surgiu ao tempo de D. Jo Ão III, aí pelos meados do século XVI, e foi apoiada por MARTim Afonso DE Sousa, a quem o rei consultara a respeito. Ao que referem as crônicas, Martim Afonso DE Sousa teria dito, por essa ocasião, que «doidice seria viver um rei na dependência de seus vizinhos, podendo ser monarca de outro maior mundo».

Ainda no século XVI, o rei FELIPE II da Espanha, que aspirava ao trono de Portugal, no que era contrariado pelas pretensões da Duquesa de Bragança, propôs a esta última ceder-lhe o Brasil, onde seu marido, o Duque de Bragança poderia investir-se no título de rei. Tal proposta mereceu o 
apoio do Cardeal D. Henrique, então ocupante do trono Português, mas não chegou a concretizar-se.

Com o falecimento de D. Henrique, foi aclamado rei o Prior de Crato, contra o qual se levantaram as armas do rei da Espanha. Ante a impossibilidade de uma resistência eficaz, pensou-se na transferência da côrte para o Brasil, tendo-se para êsse fim aprestado uma esquadra que deveria partir do Tejo.

No reinado de D. Jox̃o IV, estando em perigo a independência de Portugal, pensou o rei em abdicar a monarquia portuguêsa em favor do seu filho TEODósıo, a fim de que êste, casando-se com uma princesa da França, conquistasse para sua pátria um poderoso aliado. D. JoÃo IV viria então para o Brasil edificar o seu reinado.

Por ocasião do terremoto de Lisboa, veio novamente à baila a transferência da côrte para o Brasil, e, em 1762, quando essa cidade estêve ameaçada de invasão pelos espanhóis, a idéia começou a ser executada, e providências foram tomadas na previsão de que, a qualquer momento, a rei e a familia real embarcariam para o Brasil.

Como se vê por êsses antecedentes históricos, houve bastante tempo para a elaboração de um plano administrativo a ser adotado na hipótese, que se afigurava cada vez mais inevitável, de se ver a coroa portuguêsa obrigada a procurar refúgio nas terras do Brasil. Mesmo durante o periodo em que as relações entre Portugal e a França evoluiram para o seu ponto crítico, isto é, entre 1805 e 1807 , a elaboração do aludido plano téria sido perfeitamente viável. Ainda assim não foi objeto de cogitações.

O fato é que ao chegar ao Brasil D. Jox̃o VI não trazia um plano de administração e, ao que parece, não estava sequer com orientação firmada a respeito de certas medidas que deveriam ser tomadas, sem maiores delongas, para a adaptação da colônia ao séu novo papel de sede da monarquia.

$\mathrm{Um}_{\mathrm{m}}$ de seus primeiros e mais significativos atos, o decreto de 28 de janeiro de 1808 , que abriu os portos do Brasil a tôdas as nações amigas, lhe foi sugerido na Bahia. O próprio preâmbulo do ato em questão não deixa a respeito a menor dúvida. Nêle se contém êste trecho bastante expressivo :

«Atendendo à representação que fizestes subir a minha real presença sôbre se achar interrompido e suspenso o comércio desta Capitania, com grave prejuízo dos meus vassalos e da minha Real Fazenda, em razão das criticas e públicas circunstâncias da Europa; e querendo dar sôbre êste importante objeto alguma providência pronta e capaz de minorar tais danos; sou servido ordenar interina e provisòriamente, enquanto não consolido um sistema geral que efetivamente regule semelhante matéria...»

O sistema geral prometido pelo regente jamais foi adotado e a abertura dos portos, feita em caráter provisório, tornou-se definitiva, não obstante a rude oposição que lhe moveram os fidalgos e comerciantes lusitanos, os quais viam chegar ao fim o cômodo regime em que Portugal, como consumidor e entreposto distribuidor de tôda a produção brasileira, enchia os 
cofres de suas alfândegas, assegurava frete permanente para os seus navios mercantes e fazia a prosperidade de seus comissários e proprietários de armazéns.

Houve quem visse na confirmação tácita das disposiçõe's provisórios do decreto de 28 de janeiro de 1808 o produto da orientação administrativa do Príncipe Regente em relação ao Brasil. Mas o próprio Oliveira Lima, (1) a quem se deve a destruição de uma série de mal-entendidos que se formaram em tôrno da figura de D. Jos̃o VI, refuga semelhante opinião.

Em verdade os fatôres que impediram a revogação da medida de abertura dos portos foram a nece'ssidade da manutenção das comunicações da côrte com o resto do mundo como meio de garantir a presença de. Portugal no concêrto das nações civilizadas; o imperativo de dar escoamento à produção brasileira, o que se tornava indispensável não só para o desenvolvimento de nossa economia, como também para a arrecadação dos impostos destinados ao custeio da máquina administrativa; e a necessidade de assegurar a importação de certas utilidades essenciais que aqui ainda não eram produzidas. A êsses fatôres haveria que acrescentar as pertinazes gestões feitas perante o Principe Regente pela Inglaterra, pais que, com a abertura dos portos brasileiros e o tratado comercial de 1810 passara a ter consideráveis interêsses no Brasil. (2) Neste particular é muito expréssivo o fato de haver no tratado de amizade e comércio então concluído entre a Inglaterra e o Brasil uma cláusula que impedia a revogação do décreto de abertura dos portos.

Como sede de um govêrno reconhecido pelos demais países, o Brasil teria de assumir uma posição nova em face do direito internacional, pois aqui de'veriam ser tratados os assuntos referentes às relações exteriores da monarquia portuguêsa e estabelecidas as representações diplomáticas das nações amigas. D. JoÃo VI não trazia qualquer medida de caráter admir nistrativo para atender a essa situação; tudo veio a ser feito mais tarde, sob a pre'ssão dos acontecimentos.

A principal decisão de D. João VI no que concerne à organização da administração pública, foi a constituição do Ministério que com êle deveria partilhar as tarefas do govêrno. Esse Ministério compunha-se das pastas do Reino; da Marinha e Ultramar; e da Guerra e Estrangeiros. Juntamente com as três citadas sécretarias de Estado foi criada a Presidência do Real Erário, a qual, alguns anos mais tarde, se transformou no Ministério da Fazenda.

A direção geral da política, talvez por fôrça das circunstâncias que colocavam os interêsses da monarquia na dependência dos acontecimentos em curso na Europa, foi confiada à pasta da Guerra e Estrangeiros, cujo primeiro titular foi o Conde de Linhares. A missão de completar o aparelhamento administrativo, mediante a criação de novos órgãos e a conveniente adaptação dos que já existiam, ficou a cargo da Secretaria do Reino, vara a qual foi nomeado Fernando José de Portugal, futuro Marquês de

(1) D. João VI no Brasil - $1^{\text {a }}$ edição. Rio, 1943.

(2) Veja-se História Econômica do Brasil - Roberto Simonsen - Col. Brasiliana. 
Aguiar, que antes exercera os cargos de Governador Geral da Bahia, ViceRei do Rio de Janeiro e Presidente do Conselho Ultramarino.

VARNHAGEM (3) faz acerba crítica à maneira pela qual o Marquês de Aguiar se desincumbiu de sua tarefa e 0 acusa de, não obstante seu presumido conhecimento da situação e das necessidades do Brasil, haver para aqui transplantado, sem maior critério, instituições que na côrte já se haviam revelado inoperantes, quando não prejudiciais.

A revolução operada pela transmigração da família real não se limitou ao Brasil; refletiu-se também em Portugal, pois que dela resultou uma completa inversão de papéis. $\mathrm{O}$ aparelhamento de administração e de govêrno instituido no Brasil, outrora subordinado ao que existia em Portugal, passou para o primeiro plano, assumindo uma posição subordinante. Para tornar ainda mais acentuada essa nova disposição, o título de Secretário de Estado passou a ser privativo dos integrantes do ministério criado no Rio de Janeiro, ficando os ocupante's de iguais cargos em Portugal com o título de Secretário do Govêrno. O cargo de Presidente do Real Erário ficou existindo apenas no Brasil, pois o que havia em Portugal foi transformado numa Diretoria-Geral.

Sòmente nos assuntos que reclamassem imediata e pronta solução poderia o govêrno de Lisboa tomar decisões. Nos demais casos, obedecia a «total subordinação e dependência» dos Secretários de Govêrno aos Secretários de Estado, e do Diretor-Geral ao Presidente do Real Erário, os processos deveriam ser, sob a forma de consulta acompanhada dos respectivos pareceres, encaminhados ao Rio de Janeiro para deliberação final.

A profunda interligação dos sistemas de administração e govêrno de Portugal e do Brasil, proveniente de uma vasta rêde de interêsses comuns que não poderia ser rompida de um momento para o outro, explica a transplantação para o Rio de Janeiro das mesmas instituições através das quais a côrte dirigia seus dominios. É verdade que essa transplantação sob muitos aspectos não atendeu às conveniências do Brasil, mas não é menos verdade que com a adoção, entre nós, de uin sistema de administração inteiramente novo, a monarquia se tornaria menos apta para velar pelos negócios de Portugal, o que forçosamente acarretaria profundas conseqüências de ordem política. Por outro lado, criar-se-ia, por ocasião do retôrno da côrte a sua primitiva sede, um difícil problema de reajustamento da máquina administrativa. Se a solução adotada pelo Marquês de Aguiar, que perdia em brilho o que ganhava em prudência, produziu tão grande agitação politica em Portugal, que efeito não teria o abandono do antigo mecanismo administrativo da monarquia?

No julgamento da atuação do Marquês de Aguiar não devemos esquecer o fato de que a côrte não viera estabelecer no Brasil em definitivo, mas com o propósito de retornar a Lisboa, quando os acontecimentos o permitissem. Vistas as coisas dêsse ângulo compreende-se a ausência de grandes inovações na configuração administrativa da monarquia durante o periodo de sua permanência no Brasil, e justifica-se, sem maiores reservas, a solução imaginada pelo Marquês de Aguiar.

(3) História Geral do Brasil, vol. V. 
Os mais importantes órgãos administrativos criados por D. JoÃo VI foram, além das três secretarias de Estado, o Conselho Supremo Militar e de Justiça; o Tribunal da Mesa do Desembargo do Paço e da Consciência e Ordem; a Casa da Suplicação do Brasil; a Intendência Geral de Policia; - Erário Régio; o Conselho de Fazenda; o Banco Nacional; é a Real Junta de Comércio, Agricultura, Fábricas e Navegação. A êsses órgãos vieram juntar-se outros que, apesar, de ocuparem posição menos proeminente na estrutura da administração, tiveram notável influência no désenvolvimento do Brasil. Dêles nos ocuparemos mais tarde.

O Conselho Supremo Militar e de Justiça, criado por alvará de 1 de abril de 1808 , passou a exercer as atribuições que outrora, em Portugal, cabiam ao Conselho de Guerra, ao Conselho do Almirantado e ao Conselho de Ultramar (assuntos exclusivamente militares). Incluiam-se no âmbito de sua competência a regulamentação das fôrças de terra e mar; o julgamento dos crimes e das questões disciplinares de natureza militar; a expedição das cartas patentes das tropas de linha, da Armada Real e Brigada, bem como dos Corpos Milicianos e Ordenanças; o julgamento, em última instância, da validade das prêsas feitas pelas émbarcações de guerra, ou pelos armadores portuguêses. Mais tarde essas atribuições foram ampliadas, passando a abranger o julgamento das causas maritimas suscitadas entre os súditos de diferentes Estados (Alvará de 6 de novembro de 1810) e a apreciação e decisão final das devassas sôbre naufrágios (Alvará de 19 de novembro de 1810).

O Conselho Supremo Militar e de Justiça era integrado pelos Conselheiros da Guerra, pelos Conselheiros do Almirantado, pelos Vogais e três Ministros Togados. Concebido como um órgão de administração e jurisdição militar, teve' durante algum tempo certa importância também como tribunal marítimo, suprindo dêsse modo a ausência de uma instituição destinada a solucionar o grande número de casos oriundos da intensificação das comunicações maritimas provocada pela abertura dos portos.

O Tribunal da Mesa do Desembargo do Paço e da Consciência e Ordem teve sua origem no alvará de 22 de abril de 1808 . Era um órgão hibrido, pois que nêle se reuniam atribuições que em Portugal cabiam à Mesa do Desembargo do Paço, à Mesa da Consciência e Ordens e ao Conselho Ultramarino (assuntos não militares). Importando na fusão de três órgãos de atribuições especializadas e inteiramente diversas, a nova instituição com que se vinha sobrecarregar a administração pública brasileira possuía uma esfera de competência muito heterogênea. Cabia-lhe julgar as causas criminais em que fôssem parte os cavaleiros das ordens reconhecidas pela coroa; expedir alvarás de fiança e cartas de seguro; comutar penas e condenações; arrecadar a fazenda dos defuntos e dos ausentes; cuidar dos assuntos de interêsse dos estabelecimentos religiosos; fixar o número dos advogados e habilitar os profissionais dessa categoria ao exercício de suas funções; confirmar as sesmarias concedidas pelos governadores das capitanias e conceder, ad referendum do Príncipe Regente, as que tivessem por objeto terras do Rio de Janeiro: opinar sôbre questóes de instrução, imprensa e tratamento ao gentio. Compunha-se êsse pomposo tribunal de um Presidente, vários Desembargadores e Deputados da Mesa 
da Consciência e Ordem. Nêle funcionavam um Procurador-Geral, para zelar pelos negócios e direitos das ordens, um Juiz dos Cavaleiros para julgar as apelações criminais dos membros das citadas corporações, e um Promotor para fiscalizar a arrecadação dos bens dos defuntos e dos ausentes.

Alguns anos mais tarde, em 1811, as atribuições do tribunal foram descentralizadas e divididas pelas juntas criadas em cada capitania por um alvará de 30 de setembro. Tais juntas, que eram integradas pelo Governador, pelo Ouvidor e pelo Juiz de Fora, reuniam-se' mensalmente e expediam suas provisões em nome do Príncipe Regente.

A Casa de Suplicação do Brasil, resultante da transformação sofrida pela Relação do Rio de Janeiro, foi instituída por um alvará de 10 de' maio de 1808, como Superior Tribunal de Justiça, onde deveriam encerrar-se todos os feitos qualquer que fôsse o seu valor. Compunha-se dé um Regedor, de um Chanceler da Casa, de oito Desembargadores dos Agravos, de um Corregedor do Crime, de um Juiz dos Feitos da Coroa e Fazenda, de um Corregedor do Cível da Côrte, de um Juiz da Chancelaria, de um Ouvidor do Crime, de um Procurador dos Feitos da Fazenda e Coroa, de um Juiz da Chancelaria e sete Promotores.

A Casa de Suplicação do Brasil teve sua jurisdição reduzida por um alvará de 6 de maio de 1809, o qual restituiu à Casa de Suplicação de Lisboa a competência para apreciação dos agravos ordinários e das apelações do Pará e Maranhão, por serem mais difíceis as comunicaçõe's entre essas duas capitanias e o Rio de Janeiro.

A Intendência Geral de Polícia surgiu por fôrça de um alvará de 10 de maio de 1808. Moldada na sua congênere de Lisboa, tinha como atribuição primordial a de defender as autoridades constituidas, máxime em caso de sedição. Tocavam-lhe, também, funções de edilidade tais como: aprovar os arruamentos urbanos; abrir novas vias públicas e assegurar a conservação das já existentes; fiscalizar as construções civis; zelar pelas fontes e chafarizes; licenciar e vigiar os transportes de mar e terra, os teatros e locais de diversões públicas, os botequins, casas de jôgo e estalagens; reprimir a vadiagem e a mendicância; extinguir os incêndios; e recenséar a população. Pode-se ter uma idéia da grande variedade dos assuntos de que se encarregava a Intendência Geral de Polícia, compulsando-se o relatório de Paulo Fernandes Viana. (4)

O Erário Régio e o Conselho de Fazenda, criados em 28 de junho de 1808 , tinham por finalidade reunir sob uma única jurisdição tôdas as coisas e negócios da Fazenda Real, os quais, até então, eram objeto das jurisdições voluntária e contenciosa a cargo das Juntas de Fazenda e dos órgãos de revisão da divida passiva da Capitania do Rio de Janeiro. O Erário Régio compreendia uma Tesouraria-Mor e três Contadorias-Gerais, cuja ação se estendia a todo o Brasil e Dominios Ultramarinos. A primeira ContadoriaGeral foi confiada a tarefa de fazer entrar no Real Erário e escriturar as rendas arrecadadas no Rio de Janeiro; cabia à se'gunda contabilizar e cobrar

(4) Publicado na «Revista do Instituto Históri o» (vol. 55), sob o título Abreviada Demonstração dos Trabalhos da Policia. 
as rendas da África Oriental, Ásia Portuguêsa, Minas Gerais, Mato Grosso, Goiás e Rio Grande do Sul; e finalmente, à terceira competia a escrituração, contabilidade e fiscalização das rendas da Bahia, Pernambuco, Maranhão, Pará, Ceará, Piauí, Paraiba, Cabo Verde, Açôres, Madeira e África Ocidental.

A coordenação de todos êsses órgãos era exercida pela Mesa do Erário Régio, na qual tinham assento o Presidente, o Tesoureiro-Mor e o Escrivão da Receita.

Espécie de código de contabilidade pública, o alvará de 28 de junho de 1808 encerrava prescrições a respeito dos métodos a serem observados na escrituração dos livros de receita e despesa, no autoamento dos contratos e operações de arrecadação $e$ administração da Fazenda Real, e instituía em cada Contadoria-Geral um diário, um livro mestre, um borrador e um livro de contas-correntes para cada um dos rendimentos das estações de arrecadação, recebedoria, tesouraria e contratos administrativos. Determinava, ainda, o alvará em qưestão que, semestralmente, se procedesse ao balanço das rendas e despesas e, anualmente, se levantasse a Conta Geral do Estado, em forma de tabela, com a inclusão de tôda receita e tôda a despesa, ambas minuciosamente discriminadas.

O Conselho de Fazenda, precursor do atual Tribunal de Contas da União, exercia funções contenciosas e de fiscalização nos assuntos de interêsse da fazenda real. A êle foram transferidas as prerrogativas, autoridade e jurisdição que, em matéria fazendária, cabiam ao Conselho Ultramarino, excetuadas as referentes à povoação, terraš, culturas e sesmarias, as quais, como já tivemos ocasião de ver, foram incluidas na competência da Mesa do Desembargo do Paço.

O Conselho de Fazenda tinha um Presidente (que era o mesmo do Real Erário) e vários Conselheiros. Na conformidade do ato de sua instituição, devia êle interferir nos seguintes assuntos :

$\left.1^{\circ}\right)$ Habilitação de herdeiros de pensões ou mercês;

$\left.2^{\circ}\right)$ proce'ssamento das fôlhas da divida passiva e exame dos títulos dos credores;

$3^{\circ}$ ) organização das fôlhas anuais dos ordenados, pensões, tenças e outras obrigações a serem atendidas pelo erário real;

4.) arrematação de todos os contratos e rendas gerais da coroa;

$\left.5^{\circ}\right)$ tomada de conta dos responsáveis pela arrecadação.

O Banco Nacional do Brasil foi o segundo instituto de crédito que D. JoÃo VI lançou em nosso país. O primeiro foi um banco de comerciantes, com o capital de cem contos de réis.

O Banco Nacional do Brasil era uma instituição de maior vulto que o seu predecessor. Tinha jurisdição sôbre todo o território brasileiro e gozava de certos privilégios e garantias, entre os quais a impenhorabilidade de suas ações e o monopólio de certos atos, como os depósitos judiciais e extrajudiciais de ouro, prata e jóias, os empréstimos a juros, outrora a cargo das Ordens Terceiras e das Irmandades, bem como a venda dos gêneros privativos e administraçóes da fazenda real. Seu capital, no valor de mil 
e duzentos contos de réis, era dividido em mil e duzentas ações de igual valor, as quais podiam ser subscritas por qualquer pessoa:

Nos têrmos do alvará que o instituiu, a partir do momento em que tivesse em caixa a quantia de cem contos de réis, o Banco Nacional do Brasil podia iniciar suas operações que eram as de desconto mercantil de letras de câmbio sacadas por negociantes ou por êstes aceitas; empréstimos com garantia hipotecária, cobranças mediante comissão e depósito de valores a prêmio; emissão de bilhetes pagáveis ao portador; conversão de fundos existentes no exterior; venda dos gêneros privativos da coroa; comércio de ouro e prata, desde que tipicamente bancário.

O Banco Nacional do Brasil tinha uma Assembléia Geral composta dos quarenta maiores acionistas, os quais deveriam ser portuguêses; só na falta dêstes últimos admitiam-se pessoas de outra nacionalidade, estabelecendo-se a preferência entre elas pelo valor do capital subscrito e, na hipótese de igualdade de capitais, pela antigüidade das subscrições. Além da Assembléia Geral havia uma Junta e quatro Diretores. À Junta cabia a administração dos fundos sociais; e aos Diretores, a fiscalização das operações com vistas à fiel observância dos estatutos da sociedade. Umare outros eram nomeados pela Assembléia Geral e confirmados por diploma régio.

Para atender aos interêsses do Banco e de seus acionistas fora do Rio de Janeiro, a Junta possuia um corpo de correspondentes.

Os acionistas faziam jus a um dividendo que era fixado pela Assembléia Geral e devia ser pago semestralmente pela Junta, após o desconto de uma sexta parte, destinada à constituição de um fundo de reserva.

A Junta de Comércio, Agricultura, Fábricas e Navegação, criada por um alvará de 25 de agôsto de 1808 , tinha a feição de um tribunal. Perante ela corriam as questões de matrícula de comerciantes, registros de contratos mercantis, processamento de patentes, privilégios e marcas de fábrica, registro de navios, regulamentação do comércio marítimo, usos e costumes comereiais, e produção agropecuária.

A vistosa cúpula administrativa, cujas peças principais acabamos de descrever, foi montada sôbre a antiga estrutura da administração colonial que já não mais conciliava os interêssés do Brasil nem correspondia aos anseios do nosso povo. Por trás do aparato e dos brocados da côrte continuava o sistema das capitanias. Estas, quando D. JoÃo VI chegou ao Brasil, eram em número de dezessete, sendo dez gerais e sete subalternas. Tôdas pertenciam à coroa, pois, o regime das donatárias encerrou-se ém 1579, ao tempo da administração do Marquês de Pombal. Já depois da elevação do Brasil à categoria de Reino Unido foram criadas as capitanias de Alagoas e Sergipe d'El Rei, com elas se completando a divisão territorial do Brasil.

O desajustamento entre a organização e os métodos administrativos coloniais e o grau de desenvolvimento que a iniciativa particular imprimira ao nosso país revelava-se de diversos modos. A transferência da côrte para - Rio de Janeiro, trazendo como conseqüência a revogação de certas medidas que mantinham as conquistas da civilização e do progresso afastadas 
de nossas fronteiras, veio criar um ambiente propício às reivindicações do Brasil, no terreno da política e da administração. O regime colonial podia considerar-se definitivamente morto, quando D. Jos̃o VI partiu da Bahia para o Rio de Janeiro. A elevação do Brasil ao status de Reino Unido foi uma tardia confirmação oficial dêsse fato que era sobejamente conhecido nos principais países da Europa. Segundo Braz do Amaral, (5) foi ela sugerida por TAYLLERAND durante o congresso que se reuniu em Viena para acertar os negócios europeus após a derrota de Bonaparte.

É certo, porém, que já em 1814 D. JoÃo VI estava persuadido de que era necessário descolonizar também administrativamente o Brasil, e, com êsse objetivo, incumbiu Silvestre Pinheiro Ferreira de elaborar um plano de reforma.

Amplamente discutido, sobretudo em Portugal, o plano de SiLvestre PINHEIRO FERREIRA (6) propunha :

$\left.10^{\circ}\right)$ que D. Maria I fôsse proclamada Imperatriz do Brasil e Rainha de Portugal, e que as terras da coróa ficassem, durante a interdição de S. Majestade, divididas em duas regências, uma que abrangeria o Império do Brasil e Dominios da Ásia e da África seria confiada a D. JoÃo VI, outra que compreenderia Portugal, Açôres, Madeira e Pôrto Santo seria confiada ao Príncipe da Beira;

29) que tanto o Reino de Portugal e suas dependências, como o Império do Brasil e os dominios fôssem divididos em provincias, comarcas, distritos e freguesias, e tivessem ambos a seguinte organização:

Secretarias de Estado:

- Secretaria dos Negócios Eclesiásticos

- Secretaria dos Negócios da Justiça

- Secretaria dos Negócios da Guerra

- Secretaria dos Negócios da Marinha

- Secretaria dos Negócios da Fazenda

- Secretaria dos Negócios de Estrangeiros

- Secretaria dos Negócios de Instrução Pública.

Conselhos:

- Conselho de Estado

- Conselho Interno

- Conselho Geral

- Conselho Supremo de Justiça

- Conselho Supremo Militar

- Conselho do Almirantado

- Conselho da Fazenda

A êsses órgãos deveriam ser acrescentados o Erário Régio, a Provedoria Mor, a Chancelaria-Mor e a Cúria Patriarcal.

(5) O Brasil no Congresso de Viena de 1815 - in «Rev. do Inst. Hist. e Geográfico», vol. 175 .

(6) Reproduzido na integra pela "Rev. do Inst. Histórico", vol. 47. 
Quando se considera que nos começos do século XVIII o Brasil tinha suas principais fontes de riqueza na agricultura e na mineração, atividades que eram grandemente embaraçadas pela extrema deficiência das vias de comunicação entre o interior e o litoral, não se pode deixar de estranhar que o plano de Sillvestre Pinheiro Ferreira não previsse, com o necessário realce, a criação de órgãos destinados às questôes de viação, minas e produção agrária. Mas pelo menos à instrução pública dispensava êle a consideração com que o problema vinha figurando em quase todos os planos de reforma inculcados pelos brasileiros.

A correspondência de Silvestre Pinheiro Ferreira revela que D. João VI confiou a várias outras pessoas o estudo das bases de uma nova organização politico-administrativa para o Brasil, com o que reiterava sua convicção de que a velha estrutura colonial se tornava cada vez mais insustentável. Outros planos surgiram, como o do Conde Palmela, segundo o qual haveria três podêres: o executivo, que seria exercido, individualmente, pelo rei; o legislativo, que seria integrado pelo rei e por duas câmaras; e o judiciário, que seria constituido por tribunais independentes e inamoviveis. A limitação dêsses podêres seria alcançada, mediante a concessão, ao súditos do Estado, dos direitos de liberdade de residência e locomoção, segurança da propriedade, liberdade (moderada) de imprensa, e repartição geral dos impostos, sem distinção de classes nem privilégios. Como instrumentos de contrôle dos atos administrativos, o plano Palmela estabelecia a responsabilidade dos ministros e empregados públicos, e a publicidade de todos os atos relacionados com as rendas do Estado.

Também em Portugal a futura organização politica e administrativa do Brasil era objeto de vivo interêsse. Disso dá nítida idéia o ardor dos debates que se travaram na Universidade de Coimbra em tôrno do plano de Antônio d'Oliva de Souza Siqueira. Tal plano, não obstante ser de autoria de um português, estatuia:

19) A elaboração de uma constituição para o Reino Unido, estabelecendo-se nela que a capital do dito reino seria o Rio de Janeiro ou a Bahia.

2.) A instituição de dois Congressos, um no Brasil para onde viriam os representantes das possessões da Ásia e da África; e outro em Portugal, onde teriam assento os deputados dos Açôres e Madeira.

3. ${ }^{\circ}$ A nomeação, para Portugal, de um Vice-Rei, com todos os podêres, inclusive para conceder títulos.

4.) A proibição de serem os residentes de um dos reinos proprietários no outro.

5\%) A liberdade de comércio entre o Brasil e Portugal.

Fatôres diversos, entretanto, impediram D. Jox̃o VI de tomar uma decisão definitiva a respeito de tão importante matéria. Havia, em primeiro lugar, a irreconciliável divergência de pontos-de-vista brasileiros e portuguêses, quanto às soluções a adotar, o que colocava a coroa frente ao penoso dilema de atender as reivindicações do Brasil, com risco de ver o trono desmoronar-se em Portugal, ou satisfazer os propósitos reacionários dos portuguêses, com a inevitável conseqüência de perder para sempre o Brasil. 
Entre os próprios brasileiros a ausência de acôrdo em relação à reforma politica por todos ansiada era profunda $e$ as dissensões que dai se originavam repercutiam no seio do próprio ministério que cercava D. JoÃo VI. Êste último, que já era indeciso de natureza, se via instado em direções opostas, não tendo sequer, para melhor orientar sua deliberação, um conhecimento exato das condições reinantes em Portugal.

Quando por aqui chegou a notícia de que em Lisboa se estava elaborando uma nova constituição, produziu-se grande alvorôço. Qual seria o sentido dêsse ato politico? Representaria êle o fim da monarquia ou apenas a redução de seus podêres pela instituição de uma assembléia popular? Não se sabia ao certo. Apenas se tinha como resolvido que a referida constituição seria moldada pela da Espanha, a qual, segundo então se dizia, em matéria de liberalismo, chegava a superar as próprias conquistas da revolução francesa.

Premido pelas circunstâncias, D. JoÃo VI expediu um decreto em que determinava que o príncipe D. PEDro fôsse a Portugal, a fim de, após ouvir as representações e queixas dos povos, encaminhar as reformas, leis e melhoramentos tendentes a consolidar a Constituição Portuguêsa. Simultâneamente, no Rio de Janeiro, seriam convocadas as côrtes para o exame da constituição a ser adotada em Portugal, e sua conveniente adaptação às condições peculiares do Brasil.

A idéia de se adotar para o Brasil, com as modificações que se afigurassem necessárias, a mesma constituição que viesse a ser aprovada para Portugal encontrou forte oposição, sobretudo na Bahia, onde se verificou uma insurreição armada, e no Pará, tendo essas duas capitanias aderido ao govêrno de Lisboa e se proclamando independentes do govêrno do Rio de Janeiro.

O curioso é que se lançavam nessa atitude de oposição tanto os portuguêses mais reacionários como os brasileiros mais autonomistas. Os primeiros por entenderem que a faculdade de emendar a constituição que as côrtes portuguêsas viessem a aprovar importaria em conferir ao Brasil uma hegemonia politica de todo prejudicial; os segundos por temerem que sob o pretexto de uma solução mais adequada ao Brasil, Portugal tentasse adiar, indefinidamente, a solução do principal problema politico brasileiro, e, assim, abrir caminho a um eventual movimento de recolonização. Inspiradas em interêsses antagônicos, as duas facções propugnavam pela vigência, no Brasil, da constituição que viesse a ser adotada em Portugal.

Ante a ameaça de alastramento da insurreição liderada pela Bahia, D. JoÃo VI, em ato público e solene, jurou obediência à constituição que as côrtes portuguêsas ainda não haviam sequer aprovado.

Mas a questão constitucional estava ligada a uma outra não menos importante: a da permanência da côrte no Rio de Janeiro. Aos portuguêses parecia imprescindivel o regresso do rei a Portugal, a fim de que êste último reconquistasse as vantagens políticas e econômicas de sede da monarquia, e se suprimisse um dos principais fatôres que alimentavam o espírito de independência que no Brasil se tornava cada dia mais vigoroso. Os brasileiros, ao contrário, defendiam, ardorosamente, a permanência da côrte no Rio de Janeiro não só porque isso representava a garantia de consolidação das conquistas políticas já realizadas, como porque não lhes sorria a hipótese 
de verem o trono sediado num pais que mal readquirira a liberdade $\mathrm{e}$ se apresentava intranqüilo, desprestigiado e pobre diante do mundo.

Em março de 1821, quando por aqui chegou um ofício das côrtes de Lisboa instando pelo regresso de D. Jox̃o VI, o assunto foi submetido à apreciação do Conselho de Estado, tendo êste, contra o voto de Silvestre Pinheiro Ferreira, sugerido que D. Jo Ão VI embarcasse para Portugal, deixando D. PEDRo como regente do Brasil. E foi o que aconteceu. Com a partida de D. Jo ̃o VI encerrava-se mais uma fase da administração pública brasileira, a qual, não obstante os defeitos de estrutura e de funcionamento que a assinalaram, produziu muito bons resultados, exceto no campo econômico-financeiro.

Ao tempo em que se registravam êsses acontecimentos, o Brasil, para progredir, aceleradamente, em determinados setores, necessitava, apenas, da revogação de certas proibições que pesavam sôbre êle. Algumas dessas proibições foram decretadas pelo próprio D. Jo ̃̃o VI. Talvez, se se tivesse adotado, antes de 1808, um regime de mais liberalismo, a obra de D. Jo ̃̃o VI não formasse tão vivo contraste com a dos Governadores-Gerais ou Vice-Reis, aos quais a metrópole, através de um vigilante mecanismo de restrições, impediu uma atuação mais eficiente. Instalado no Brasil, D. JoÃo VI passou a sentir, pessoal e diretamente, os incômodos efeitos dessa severa politica de proibições, e, como ela tornasse asfixiante o ambiente para a vida da côrte e os interêsses da coroa, tratou de suprimi-lał Daí proveio o rápido florescimento dos diferentes setores das atividades públicas e particulares. Onde, anteriormente, por fôrça das referidas proibições nada existia, começaram a surgir as iniciativas a que hoje temos de remontar, quando estudamos certos aspectos da vida brasileira.

Objetivamente considerada, postos de lado os fatôres sentimentais e levadas em conta apenas as circunstâncias históricas que verdadeiramente a explicam, a obra administrativa de D. Jo ̃̃o VI é digna de admiração pelos grandes benefícios que trouxe ao Brasil.

Durante largo tempo a instrução pública não constituiu, no Brasil, um encargo do Estado. Dela se ocupavam os jesuítas que a ministravam através de seus colégios, seminários e escolas de primeiras letras. Quando a Companhia de Jesus foi expulsa de Portugal, a obra que os diligentes religiosos vinham realizando foi interrompida de chôfre e, muito embora a coroa tivesse chamado a si o problema da instrução pública, esta entrou em colapso, pela impossibilidade de se constituir com a renda do impôsto destinado a tal fim (7) uma rêde escolar capaz de substituir a que os jesuitas haviam difundido pelo território brasileiro.

Fazendo um balanço da situação como ela se apresentava em 1805 , dizia Moreira d'Azevedo: (8)

"Era deplorável a instrução pública no Brasil. A política despótica de Portugal não tolerava que houvesse tipografia alguma

(7) Esse impôsto, com a denominação de subsidio litetário, incidia sôbre a aguardente e bebidas espirituosas (Lei de 10 de novembro de 1772).

(8) A Instruţão Pública nos Tempos Coloniais - in "Rev. do Inst. Histórico", vol. $52,2^{\circ}$ parte. 
em sua colônia da América, de sorte que o povo se achava no mesmo estado, como se nunca se houvesse inventado a imprensa. Raros eram os livros que circulavam, e não havia o menor gôsto pela leitura. As escolas eram muito poucas e mal dirigidas; havia diminuta freqüência de alunos e geralmente as mulheres não aprendiam a ler.

Só havia escolas nas cidades e vilas mais importantes, enquanto os outros pontos do país viviam na mais completa ignorância. Excetuados os seminários e as escolas monásticas, só podia beber-se alguma instrução freqüentando-se as poucas aulas régias de latim, de retórica e de filosofia, e o mui limitado número de escolas de instrução elementar. Os professôres mal retribuídos e pouco considerados não tinham uniformidade no ensino nem aptidão e aos alunos infligiam castigos corporais excessivos e infamantes."

Os brasileiros, entretanto, estavam vivamente interessados em melhorar - aparelhamento do ensino público e vinham-se batendo pela criação, entre nós, de uma universidade nos moldes da de Coimbra. Quando D. JoÃo VI se estabeleceu na Bahia, em principios de 1808, os comerciantes locais lhe propuseram a criação de uma universidade, prontificando-se a fornecer os capitais necessários ao empreendimento. Além de um ato público de louvor e da distribuição de algumas comendas, nada mais resultou do generoso oferecimento.

O primeiro ato de D. João VI com referência ao ensino foi a carta régia de 18 de fevereiro de 1808, em virtude da qual foi instituída uma Escola de Cirurgia, no Hospital da Bahia, de acôrdo com as sugestões do médico brasileiro José CorReIA PICANÇo que ocupara uma cátedra na Universidade de Coimbra e exercera o cargo de Cirurgião-Mor do Reino. A citada escola destinava se ao ensino da cirurgia, da anatomia e da arte obstétrica, num curso de quatro anos com aulas teóricas e práticas. (9) Cinco dias após era criada uma aula de economia politica, sendo designado para ministrar as respectivas lições JosÉ DA SiLVA LISBOA que gozava da reputação de grande entendedor da matéria.

Em 1809, fundava-se a Academia de Guardas Marinha, a qual foi aparelhada com instrumentos, livros, modelos, máquinas, cartas e planos idênticos aos de sua congênere de Lisboa. Seu currículo compreendia matemática, física, navegação, artilharia e desenho. Ainda em 1809 surgiram as instruções reguladoras do provimento dos lugares do magistério público, as quais mandavam que se obedecesse a carta régia de 19 de agôsto de 1799 . onde se previa a realização de concurso público perante uma comissão de três examinadores.

Em 1810 instituia-se um curso regular de ciências exatas e de observação, visando à sua aplicação aos estudos militares e práticos. Dois anos mais tarde iniciava-se o estudo de quimica num laboratório para tal fim criado no

(9) Em 1815, após a criaçăo do lugar de Diretor dos Estudos de Medicina da Côrte e Reino do Brasil, êsse curso passou a ter a mesma organização do que foi criado no Rio de Janeiro em abril de 1813 (Carta Régia de 29-12-815). 
Rio de Janeiro. O regulamento dado ao lente da cadeira de quimica estabelecia a associação entre o ensino teórico, as provas práticas e as atividades de campo, destinando-se estas últimas, que seriam realizadas no período de férias, à coleta e exame de amostras de solo e substâncias minerais dos arredores da cidade. Eram previstas ainda a elaboração de um manual de quimica em lingua portuguêsa e a organização de um museu de mineralogia. Nas mesmas bases o ensino de quimica estendeu-se à Bahia cinco anos mais tarde.

Outro ramo do ensino que mereceu a atenção do govểrno central, no periodo de 1812 a 1814 , foi o agrícola, criando-se para desenvolvê-lo o curso de agricultura da Bahia. As instruções para êle baixadas pelo Conde da Barca denotavam uma concepção bastante avançada da metodologia e finalidades do ensino agricola, e se referiam à melhoria das sementes, às experiências para a aclimatação de plantas exóticas, à conservação da fertilidade do solo, e ao emprêgo de melhores instrumentos para o amanho das terras.

Em 1817 foram criadas aulas de desenho e história em Vila Rica e em seguida (1818) na Bahia, onde passou a funcionar também uma escola de música; e finalmente em 1819 fundava-se a cadeira de farmácia na Escola Médico Cirúrgica da Bahia, e as de filosofía e retórica na cidade mineira de Paracatu. Em 1820 fundou-se a Real Academia de Desenho, Pintura. Escultura e Arquitetura, e instituíram-se doze bôlsas de estudos para jovens que possuissem aptidões para a medicina e não pudessem custear os respectivos estudos.

जuth 4 यो

Outras instituições criadas entre 1808 e 1821 , embora não possam, a rigor, ser arroladas entre as de ensino, prestaram inestimáveis serviços à causa da instrução pública e da cultura. Entre elas merecem destaque o Jardim Botânico do Rio de Janeiro, fundado em 13 de junho de 1808, a Imprensa Régia, fundada em 13 de maio de 1808, o Arquivo Central, fundado em 7 de abril de 1808, a Biblioteca Real que foi franqueada ao público em 1810 e o Museu Real, fundado em 1818.

O quadro com que Moreira d'AzEvedo fixou o atraso em que se encontrava a instrução pública no comêço do século XIX não é pior que o que se poderia pintar para dar uma idéia das precárias condições da saúde e da higiene públicas. Pode-se imaginar o que ia nesse terreno se se considerar que as condições atribuladas em que se processou o povoamento, sob as ameaças dos indios e dos invasores estrangeiros, determinaram o amontoamento das populações nos locais que ofereciam maior segurança e melhores meios de defesa. A promiscuidade, ajudada pela pobreza dos recursos de saneamento, criava ambiente propício às doenças, cujo combate constituía, no mais das vêzes, função dos curandeiros e curiosos, pois o número de pessoas habilitadas para o exercício da medicina (licenciados, como então se dizia) e serviços auxiliares era diminuto. Querendo traduzir em poucas e incisivas palavras o sombrio panorama sanitário do Brasil colonial, afirmou Capistrano de ABreu que «Da higiene pública incumbiam-se as águas da chuva, os raios do sol e os diligentes urubus".

Em companhia de D. João VI vieram para o Brasil alguns dos melhores médicos da metrópole, os quais, impressionados com o que lhes foi dado 
observar, quer na Bahia, quer no Rio de Janeiro, propuseram a adoção de algumas providências, visando à organização dos serviços de saúde pública.

Anuindo a essas idéias, D. João VI, por atos de 7 e 9 de fevereiro de 1808, restabeleceu os cargos de Cirurgião-Mor dos Exércitos e de Físico-Mor do Reino, os quais reunidos constituíam, pelo conjunto de suas atribuições, uma espécie de inspetoria geral de saúde pública, tendo a seu serviço uma justiça especializada a cargo de um desembargador a quem competia dirigir e julgar os processos relativos às infrações das normas da polícia sanitária.

Ao Cirurgião-Mor e a seus delegados nas capitanias cabia exercer o contrôle das parteiras, dos sangradores, dos dentistas, dos algebristas e dos aplicadores de ventosas e bichas, bem como a fiscalização do ensino e exercício da cirurgia. Ao Físico-Mor e seus delegados nas capitanias competia tôda a matéria referente ao ensino e exercício da medicina, às questões entre médicos e clientes, à exploração de farmácias e ao saneamento das cidades.

Essa organização ampliou-se e aperfeiçoou-se mais tarde, por fôrça do decreto de 28 de julho de 1809, que criou o cargo de Provedor-Mor da Saúde da Côrte e do Estado do Brasil, e do regimento do citado cargo, baixado em 22 de janeiro de 1810.

Verdadeiro código sanitário, o Regimento do Provedor-Mor da Saúde começava por levar em conta os problemas provocados pela abertura dos portos e conseqüente intensificação do comércio maritimo. Visando evitar a propagação de moléstias contagiosas pelas equipagens e gêneros alimentícios vindos do exterior, estabelecia a visita sanitária aos navios, antes que êstes atracassem, e dispunha sôbre a construção de um lazareto, para quarentena das embarcações nos casos suspeitos. Cuidava dos alimentos destinados à população, coibindo o hábito de deixá-los expostos ao tempo, mandando que se construísse um armazém para guardá-los e só permitindo que fôssem distribuídos ao consumo, após a competente inspeção sanitária. Determinava que os açougues e matadouros fôssem vistoriados, para efeito de fechamento dos que nẫo satisfizessem determinadas condições de higiene. Mandava que se exercesse severa fiscalização das boticas, especialmente no que dissesse respeito à dosagem, pureza e autenticidade das drogas, prescrevendo pesadas penas para os casos de fraude. E não se esquecia, sequer, de mandar estabelecer, nos arredores das cidades, pastagens onde os animais destinados à alimentação deveriam ficar em repouso antes do abate.

Outras realizações da administração de D. JoÃo VI no campo da saúde pública foram a intensificação do emprêgo da vacina, a criação de uma enfermaria especializada para doentes mentais na Santa Casa de Misericórdia do Rio de Janeiro, e a fundação de um leprosário, no qual, já em 1818 , estavam internados oitenta e quatro hansenianos.

Enquanto eram tomadas, no setor da instrução e da saúde públicas, as providências que acabamos de mencionar, cuidava D. JoÃo VI de organizar a economia brasileira. Já os nossos portos haviam sido abertos ao comércio das nações amigas. Isso determinava maior animação nos negócios, mas em compensação criava necessidades novas, para as quais o Brasil estava completamente desaparelhado, em virtude da politica reacionária contra êle posta em prática pela metrópole. 
Sempre que se tratara de proteger os interêsses dos portuguêses, a coroa não trepidara em destruir florescentes ramos da economia brasileira. Em 1692, com o propósito exclusivo de beneficiar a Companhia de Comércio, proibira a fabricação do hidromel e da aguardente, medida que produziu forte abalo, nas capitanias que se dedicavam à cultura da canal-de-açúcar; quando em 1712 a febre dos diamantes atingiu a sua mais alta temperatura, o regime das proibições chegou ao desatino de liquidar os engenhos e plantações de cana-de-açúcar em Minas, e de impedir a abertura de estradas de ligação entre as zonas de mineração e as demais capitanias; em 1730 , numa tentativa desesperada de suprimir o contrabando do ouro, a coroa vedava, sob pena de confisco de bens e deportação para a Índia, o exercicio da profissão de ourives; e em 1785, querend̦o dar uma prova de sua paternal proteção à indústria da metrópole, mandava extinguir as fábricas e manufaturas de algodão, linho, sêda, prata e outras existentes no Brasil.

D. JoÃo VI teve, naturalmente, que revogar tôdas essas proibições. Pode-se por isso dizer que o seu grande instrumento de administração no campo econômico foi a revogação. Ao alvará de 28 de janeiro de 1808 , que suspendeu o bloqueio dos portos brasileiros, passo decisivo para a nossa emancipação econômica e politica, seguiu-se o de $1^{\circ}$ de abril do mesmo ano, que revogava o de 5 de janeiro de 1785 e permitia o estabelecimento, no Brasil e nos Domínios Ultramarinos, de «todo gênero de manufaturas, sem excetuar alguma». As disposições dêsse alvará foram completadas pelas de um outro baixado em 18 de abril de 1809 , no qual se dispunha:

1\%) que ficaria isenta de todo e qualquer impōsto nas alfândegas a matéria-prima destinada ao uso das fábricas brasileiras;

$2^{\circ)}$ que os produtos da indústria manufatureira do Brasil não pagariam impôsto de exportação:

39) que da renda da Loteria Nacional do Estado, a ser criada, se reservaria, anualmente, a quantia de sessenta mil cruzados para a constituição de um fundo destinado a empréstimos visando à aquisição de novas máquinas e equipamentos industriais;

$4 .^{\circ}$ ) que aos inventores de quaisquer engenhos ou processos de trabalho novos seria assegurado o privilégio de explorá-los, com exclusividade, pelo prazo de quatorze anos;

$5^{\circ)}$ que seriam diminuidos numa proporção de cinqüenta por cento os direitos alfandegários sôbre os materiais empregados na construção e armação de navios;

$\left.6 .^{\circ}\right)$ que seria reduzido na medida do possivel o recrutamento militar de trabalhadores agrícolas.

Dadas as características de sua economia e a deficiência de seu mercado interno, o Brasil dependia do exterior, não só para obter uma extensa série de utilidades, como para dar vazão aos seus produtos. Sobrevindo, por fôrça dos acontecimentos verificados na Europa, a supressão do comércio com Portugal, procurou D. Jo ̃̃o VI recompor o quadro de nossas importações e exportações, mediante um tratado comercial com a Inglaterra. Êsse tratado, que foi assinado em 1810 , concedia às mercadorias inglêsas um 
tratamento privilegiado, fixando-lhes um impôsto ad valorem inferior ao que incidia sôbre as mercadorias portuguêsas.

Roberto Simonsen (10) criticou o tratado de 1810, atribuindo-lhe, entre outros efeitos danosos ao Brasil, o desestimulo e asfixia da incipiente indústria brasileira, em virtude da concorrência das mercadorias inglêsas, mas reconhece que êle foi um fator importante de nossa independência politica, já que representou a quebra definitiva dos privilégios comerciais de Portugal, em relação a nossos portos e nossos produtos.

Parece-nos que só êste último efeito bastaria para enaltecer o mencionado tratado, ainda que se pudesse afirmar, acima de qualquer dúvida, a possibilidade de conciliação entre as necessidades do Brasil em matéria de artigos manufaturados e a reclamada proteçấo para a indústria que se pretendia instalar entre nós.

Em realidade essa conciliação não era assim tão fácil. Dizer que teria sido mais vantajoso ao Brasil um tratado com os Estados Unidos, seria deixar cômodamente de lado, como se isso nenhuma importância apresentasse, a situação internacional da época.

Por acaso não representaria a assinatura de um tratado com os Estados Unìidos um ato inamistoso do Reino Unido para com a sua aliada Inglaterra? A monarquia portuguêsa, ainda não refeita do abalo por que passara, tinha importantes interêsses internacionais, para cuja defesa a aliança com a Inglaterra era decisiva. Por outro lado, qualquer acôrdo comercial com o Brasil ficaria reduzido a mera formalidade, a menos que fôsse feito com uma nação que pudesse tomar exclusivamente a seu cargo o transporte marítimo, pois para isso estávamos completamente desaparelhados. Neste particular nenhuma outra nação oferecia melhores condições que as da Inglaterra, sendo de notar que esta ainda tinha a seu favor uma longa tradição de comércio com Portugal.

Outra questão de primordial importância para a economia brasileira era c da moeda e do crédito. Com relação a ela tomou D. João VI algumas providências, como a revogação da proibição de circularem nas capitanias do interior as moedas de ouro, prata e cobre que circulavam no litoral (Alvará de $1^{\circ}$ de setembro de 1808); a criação do Banco Nacional do Brasil, a que já nos referimos noutra passagem destas notas; a regulamentação das execuções, por dividas, dos engenhos e lavouras de açúcar (Alvará de 21 de janeiro de 1809); o restabelecimento dos contratos de câmbio maritimo que haviam sido proibidos, no Brasil. por um Alvará de 1957.

Não se esqueceu D. JoÃo VI do problema imigratório, tanto assim que ainda em 1808, mandava vir dos Açôres mil e quinhentas famílias para trabalhos de lavoura no. Rio Grande do Sul. Um pouco mais tarde removeu um dos mais sérios obstáculos ao incremento da imigração, revogando a proibição de serem concedidas sesmarias a estrangeiros (Decreto de 25 de novembro de 1808). Graças a esta última medida pôde o Brasil receber considerável corrente de imigrantes, entre os quais os suecos e alemães que desenvolveram a fundição de ferro em Ipanema e Minas Gerais, e os suiços

(10) Op. cit. 
que, em virtude de um tratado internacional aprovado em 6 de maio de 1818 , vieram estabelecer-se numa grande colônia, - célula da atual cidade de Friburgo.

A recapitulação da obra administrativa de D. JoÃo VI não estará completa sem algumas referências ao interêsse que ela dispensou às artes e à pesquisa científica. Neste último domínio merece destaque a contratação, em 1815, de FrEYZEN e SEllow para a realização de pesquisas de história natural, antropologia e etnografia. Dois anos mais tarde, foi o Brasil visitado por duas notáveis missões científicas, uma bávara e outra austriaca. Da primeira faziam parte SpIx e Martius, a quem se deve a classificação dos vegetais do Brasil, e a determinação do seu valor para o comércio e a medicina; da segunda, que era chefiada pelo professor VAN Schreibers, diretor do Museu Imperial de História Natural de Viena, faziam parte conspícuos especialistas em botânica, antropologia, mineralogia e biologia. 